\title{
Geolokasi Mobile Dalam Upaya Mengurangi Pelanggan Yang Menunggak Pembayaran Listrik
}

\author{
Yessy Asri $^{1}$; Irma Wirantina Kustanrika ${ }^{2}$; Muhamad Jafar Elly ${ }^{3}$; Thalia Grasella Tangkilisan ${ }^{4}$ \\ ${ }^{1,3,4}$ Jurusan Teknik Informatika, Institut Teknologi PLN, Jl. Lingkar Luar Duri Kosambi \\ Cengkareng, Jakarta Barat, Indonesia 11750 \\ ${ }^{2}$ Jurusan Teknik Sipil, Institut Teknologi PLN, Jl. Lingkar Luar Duri Kosambi \\ Cengkareng, Jakarta Barat, Indonesia 11750 \\ ${ }^{1}$ yessyasri@itpln.ac.id \\ ${ }^{2}$ irmawirantina@itpln.ac.id \\ 3 jafarelly@itpln.ac.id \\ ${ }^{4}$ grasheylatangkilisan@gmail.com
}

\begin{abstract}
PT PLN (Persero) is one of the companies providing electricity in Indonesia that supply electrical energy to the customers which spread throughout Indonesia. This company always tries to provide the best service to the electricity users. The various efforts have been done by PLN to realize its vision and mission. Many problems come to the company, but PLN always tries to handle them very well. One of the problems is how to make a bill to those customers that often delin-quent of electricity payment. In conventional method, the field officers usually make a bill to customers directly. This method is not effective because the field officers often forget the customer's location and billing time. Beside that, the customer billing files also may be lost or scatterd everywhere primary to those that are in arrear. For this reason, the authors then do a research to make an easy in billing processing by using geolocation tagging method or geotag. This research produces a mobile geolocation system by using map that shows the PLN's customers distribution not only paid customers but also unpaid customers yet. This research result is hoped giving a benefit to PLN's officers to increase their best service to customers also helping them to monitor the customers systematically by using this mobile geolocation application system.
\end{abstract}

Keywords: Customer, Monitoring, Geolocation, Mobile, In arrears

\begin{abstract}
ABSTRAK
PT PLN (Persero) adalah salah satu perusahaan penyedia listrik di Indonesia yang memasok energi listrik kepada pelanggan yang tersebar di seluruh Indonesia. Perusahaan ini selalu berusaha memberikan layanan terbaik kepada pengguna listrik. Berbagai upaya telah dilakukan oleh PLN untuk merealisasikan visi dan misinya. Banyak masalah datang ke perusahaan, tetapi PLN selalu berusaha menanganinya dengan baik. Salah satu masalah adalah bagaimana membuat tagihan kepada pelanggan yang sering menunggak pembayaran listrik. Dalam metode konvensional, petugas lapangan biasanya membuat tagihan ke pelanggan secara langsung. Metode ini tidak efektif karena petugas lapangan sering lupa lokasi pelanggan dan waktu penagihan. Selain itu, file tagihan pelanggan juga dapat hilang atau tersebar di mana-mana yang utama bagi mereka yang menunggak. Untuk alasan ini, penulis kemudian melakukan penelitian untuk mempermudah dalam penagihan pemrosesan dengan menggunakan metode geolocation tagging atau geotag. Penelitian ini menghasilkan sistem geolokasi mobile dengan menggunakan peta yang menunjukkan distribusi pelanggan PLN tidak hanya pelanggan berbayar tetapi juga pelanggan belum dibayar. Hasil penelitian ini diharapkan memberi manfaat bagi petugas PLN untuk meningkatkan layanan terbaik mereka kepada pelanggan juga membantu mereka memantau pelanggan secara sistematis dengan menggunakan sistem aplikasi geolokasi seluler ini.
\end{abstract}

Kata Kunci: Pelanggan, Monitoring, Geolokasi, Mobile, Menunggak 


\section{PENDAHULUAN}

PT PLN (Persero) adalah salah satu penyedia energi listrik di Indonesia yang akan memasok energi listrik untuk setiap pelanggan, dan berusaha untuk memenuhi permintaan pelanggan dengan memberikan layanan terbaik bagi pelanggan sesuai permintaan, salah satu hal yang dilakukan adalah layanan yang termasuk pengumpulan data pelanggan, pemadaman listrik, pembayaran listrik dan instalasi baru. Masalah paling umum yang dihadapi oleh PLN saat ini adalah masih banyak tunggakan pembayaran dari pelanggan PLN karena masih ada pelanggan yang tidak memiliki kesadaran untuk melunasi tagihan listrik mereka [1]. Tindakan PLN masih tidak efisien dan penanganan tindakan oleh petugas lapangan masih menggunakan surat peringatan yang diberikan kepada pelanggan yang menunggak. Dalam hal ini yang menangani masalah pelanggan adalah UP3. Berdasarkan data dan informasi yang diperoleh dengan sistem penanganan pelanggan nakal oleh PT PLN (Persero) UP3 Cengkareng, yang mengumpulkan tunggakan pelanggan, membayar tagihan pelanggan di tunggakan, mengakhiri listrik jika pelanggan yang bersangkutan belum melunasi tunggakan.

Mengenai instalasi baru, PLN menyediakan situs web yang dapat digunakan oleh pelanggan untuk melakukan registrasi baru tetapi tidak dapat melihat apakah masih ada tunggakan atau tidak. Dalam penelitian [2] [3] mengatakan sistem informasi instalasi listrik baru dapat membantu perusahaan dalam mengelola data instalasi baru untuk menghindari akumulasi data dan pencarian data.

Kebutuhan informasi dalam bentuk peta, GIS (Sistem Informasi Geografis) adalah salah satu bidang pemetaan yang kini banyak digunakan dalam berbagai kebutuhan. Dengan perkembangan teknologi yang telah merambah ke semua aspek kehidupan saat ini salah satunya adalah ponsel, yang ditandai dengan kelahiran teknologi smartphone. Kelebihan perangkat smartphone adalah teknologi GPS (Global Positioning System) terintegrasi. Ini memungkinkan pengembang untuk mengambil keuntungan dari nilai geografis teknologi GPS dalam bentuk koordinat. Salah satunya dapat menggunakan fungsi penandaan geolokasi untuk dapat menandai lokasi menggunakan koordinat lokasi yang ada di alamat, dapat membantu menambahkan informasi posisi data GPS (bujur, lintang dan ketinggian) [4] [5]. [6] Mengatakan bahwa menggunakan penandaan geolokasi mendapat peringkat tertinggi dibandingkan dengan menggunakan fungsi lain. [7] Mengatakan aplikasi geolokasi memudahkan pengguna dalam proses pelaporan bencana banjir.

Dalam penggunaan smartphone saat ini lebih banyak menggunakan android yang memiliki desain antarmuka yang lebih menarik, juga memiliki tampilan yang bagus namun tetap sederhana untuk memberikan kemudahan kepada pengguna dalam memahami penggunaan aplikasi android [8] [9]. [10] Mengatakan sistem persediaan yang ada dapat mengelola dan memanipulasi data persediaan dengan memanfaatkan 2D-barcode, ada juga aplikasi yang dapat membantu masyarakat dalam menyampaikan masalah yang ada di sekitar mereka dengan menggunakan aplikasi web atau android dan juga dapat memproses foto pengguna dan lokasi titik masalah pada peta [11].

Untuk sistem yang baru, PT PLN (Persero) dapat memproses data pelanggan baik menunggak atau tidak dan memantau status pelanggan apakah pelanggan telah membayar atau menunggak, jika masih menunggak petugas akan memproses tindakan berdasarkan lama tunggakan. Ada 4 hasil klasifikasi yang akan ditampilkan pada peta dalam menentukan tunggakan pelanggan, yaitu lembar laporan petugas (LBR) 1, yaitu pelanggan yang menunggak selama 1 bulan, akan ditandai dengan penanda lokasi hijau yang akan diberikan tindakan dari petugas, yaitu penyegelan MCB, LBR 2, yaitu pelanggan yang menunggak selama 2 bulan akan ditandai dengan penanda lokasi berwarna kuning yang akan diberikan tindakan dari petugas yaitu pemutusan kabel SR (koneksi rumah), LBR 3 yaitu pelanggan tunggakan selama 3 bulan akan ditandai dengan penanda lokasi merah yang akan 
diberikan tindakan dari petugas yaitu pembongkaran meteran. Sedangkan untuk pelanggan yang tidak memiliki tunggakan, penanda lokasi adalah ungu.

\section{METODE PENELITIAN}

Metode penelitian untuk mengurangi pelanggan dalam tunggakan pembayaran listrik ditunjukkan pada gambar berikut:

Data

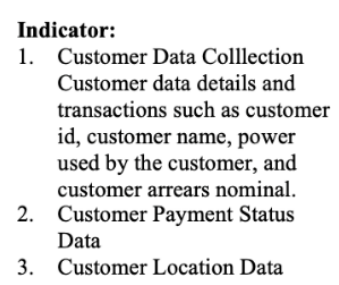

PreProcessing

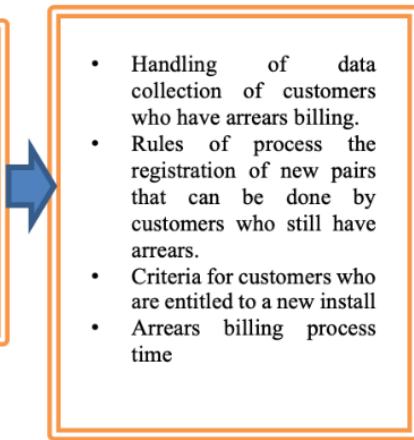

Process

Output

Gambar 1. Metode Penelitian

\section{HASIL DAN PEMBAHASAN}

Pada tahap ini dilakukan fase programming dalam bentuk hasil perancangan aplikasi monitoring pelanggan, aplikasi ini diimplementasikan menggunakan bahasa pemrograman Perl Hypertext Processor (PHP) serta JSON dan berikut adalah implementasi sistem secara keseluruhan. Aplikasi monitoring pelanggan ini dapat digunakan oleh petugas lapangan yang memiliki hak akses tersendiri terhadap aplikasi.

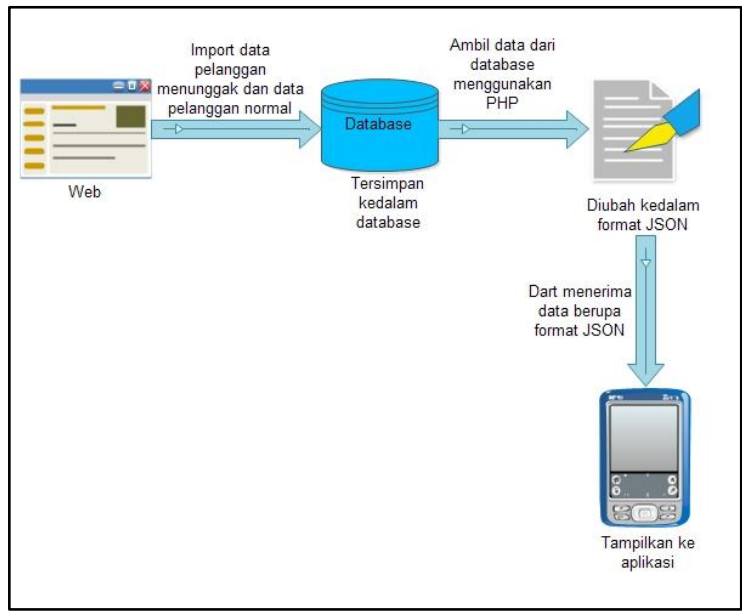

Gambar 2. Skema Hubungan antara Web dengan Aplikasi Android 


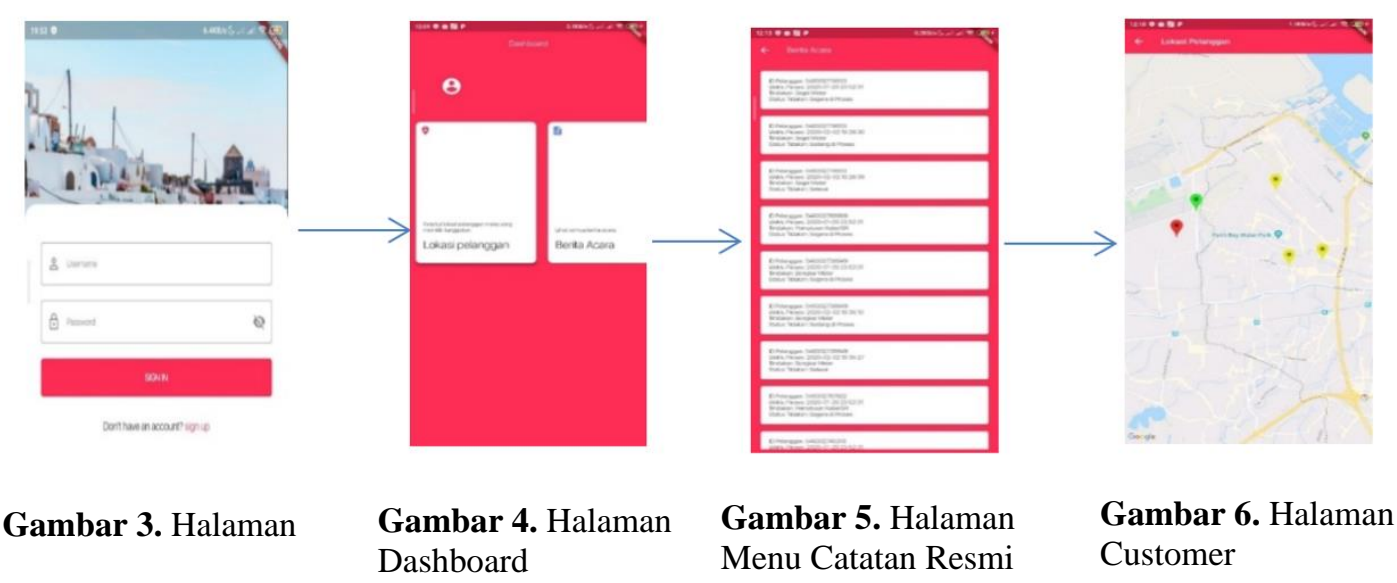

Gambar 3 hingga Gambar 6 menunjukkan cara memproses geolokasi pelanggan. Pertama, halaman login meminta petugas untuk memasukkan nama pengguna dan kata sandi pelanggan. Kemudian, tampilan halaman dashboard muncul dengan beberapa opsi menu. Selanjutnya, petugas membuat laporan resmi melalui menu laporan resmi. Menu ini berfungsi untuk menampilkan rekapitulasi tindakan petugas di lapangan termasuk waktu. Terakhir, lokasi pelanggan muncul di peta dengan empat warna berbeda. Warna titik diklasifikasikan berdasarkan laporan catatan tunggakan pelanggan. Poin hijau menunjukkan bahwa pelanggan tidak membayar tagihan selama sebulan dan sanksi adalah meteran listrik tidak berfungsi. Poin kuning menunjukkan bahwa pelanggan tidak membayar tagihan selama dua bulan dan kabel listrik terputus sebagai sanksi. Poin merah menunjukkan bahwa pelanggan tidak membayar tagihan selama tiga bulan dan sanksi untuk ini adalah meteran listrik yang akan dikembalikan oleh petugas. Poin ungu menunjukkan bahwa tidak ada masalah dengan penagihan pelanggan. Status tindakan dari setiap proses akan diperbarui ketika petugas menekan tombol aksi.

Klasifikasi warna untuk lokasi pelanggan dapat dilihat dalam kode sumber berikut ini:

$$
\begin{aligned}
& \text { if (office.lbr }==1 \& \& \text { office.status }==\text { 'Menunggak') } \\
& \text { markerColor }= \\
& \text { BitmapDescriptor.defaultMarkerWithHue(BitmapDescriptor.hueGreen); } \\
& \text { \} else if (office.lbr }==2 \& \& \text { office.status }==\text { 'Menunggak') } \\
& \text { markerColor }= \\
& \text { BitmapDescriptor.defaultMarkerWithHue(BitmapDescriptor.hueYellow); } \\
& \quad \text { ' else if (office.lbr }==3 \& \& \text { office.status }==\text { 'Menunggak') } \\
& \text { markerColor }= \\
& \text { BitmapDescriptor.defaultMarkerWithHue(BitmapDescriptor.hueRed); } \\
& \text { \} else \{ } \\
& \text { markerColor }= \\
& \text { BitmapDescriptor.defaultMarkerWithHue(BitmapDescriptor.hueViolet); } \\
& \text { \} }
\end{aligned}
$$

Lbr dalam kode sumber disingkat dari kata 'lembar yang berarti lembar laporan petugas. 'Menunggak' di sini berarti tidak membayar tagihan. Ada tiga lembar laporan berdasarkan lama tunggakan. Jika lbr sama dengan 1, itu berarti pelanggan tidak membayar tagihan selama satu bulan. 
Lokasi untuk kondisi ini ditandai dengan titik warna hijau. Jika lbr sama dengan 2, itu berarti pelanggan belum membayar tagihan selama 2 bulan. Lokasi untuk kondisi ini ditandai dengan titik warna kuning. Jika lbr sama dengan 3, itu berarti bahwa pelanggan belum membayar tagihan selama 3 bulan. Lokasi untuk kondisi ini ditandai dengan titik warna merah. Warna terakhir dalam kode sumber adalah violet yang berarti tidak ada tunggakan pelanggan. Klasifikasi oleh pewarnaan ini memudahkan petugas mengambil tindakan sebagaimana dijelaskan di atas. Hasil klasifikasi untuk setiap warna dapat ditunjukkan pada gambar 7 hingga gambar 10 di bawah ini.

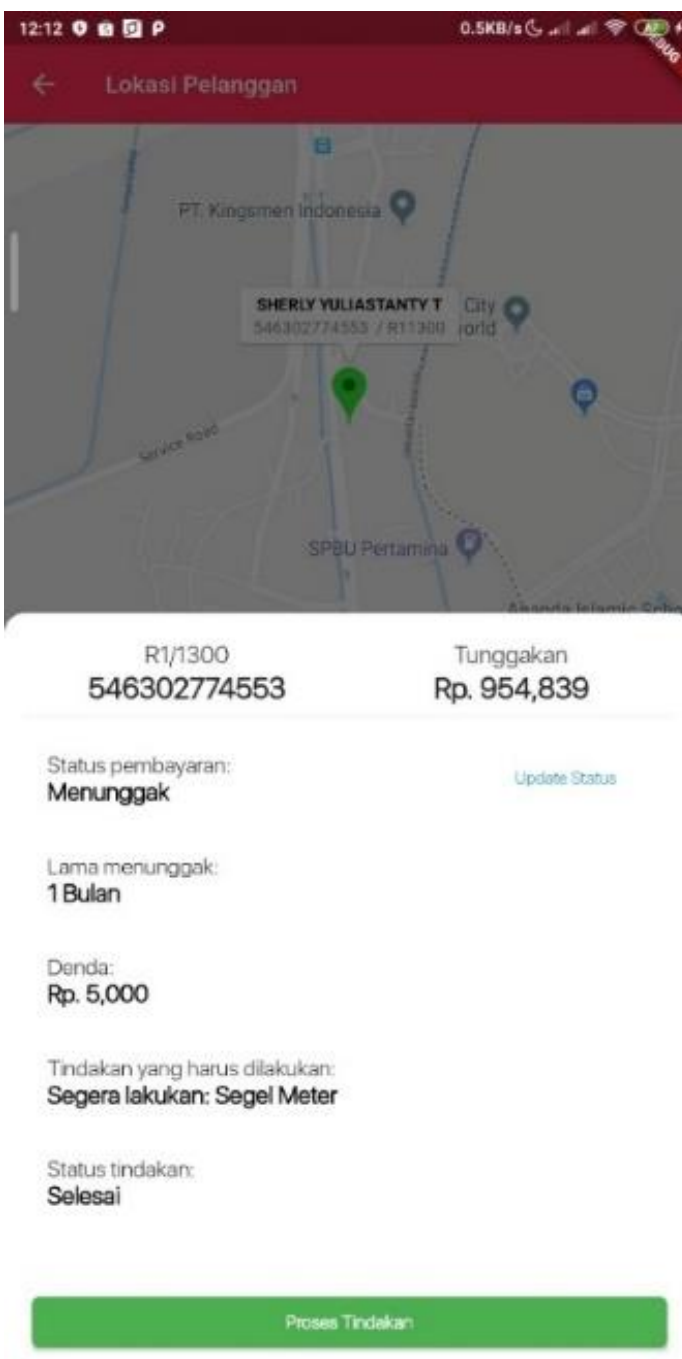

Gambar 7. Lembar Laporan 1 untuk 1 bulan tunggakan
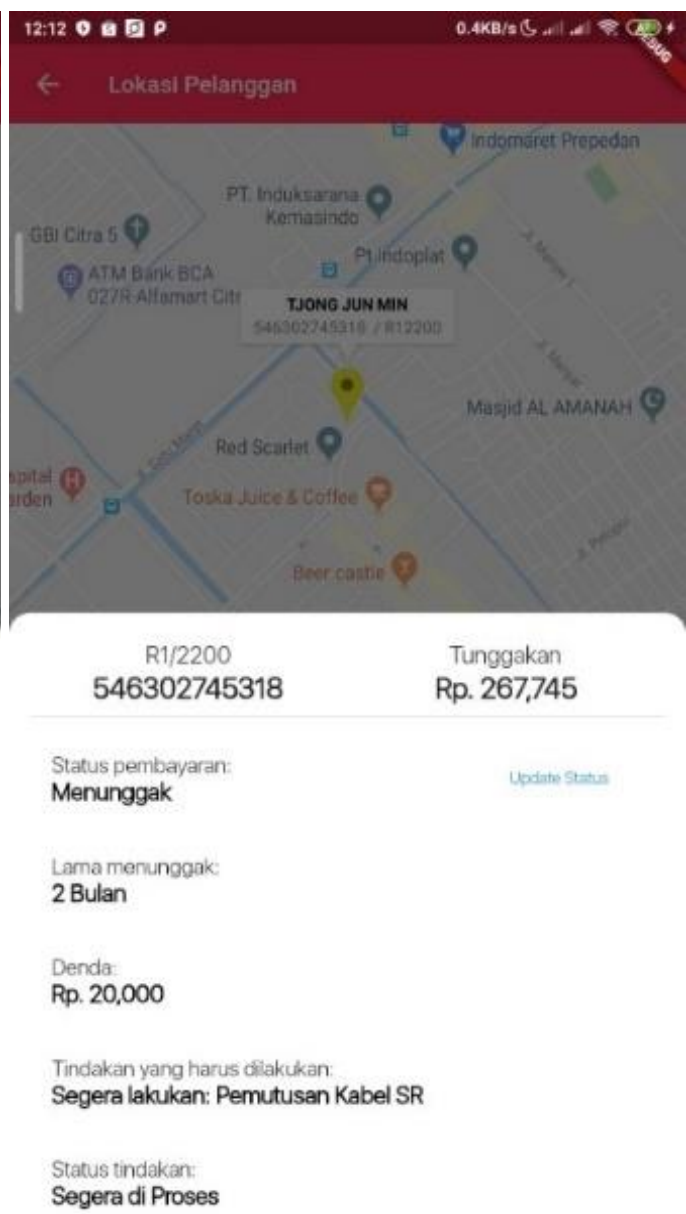

Proes Tindakan

Gambar 8. Lembar Laporan 2 untuk 2 bulan tunggakan 


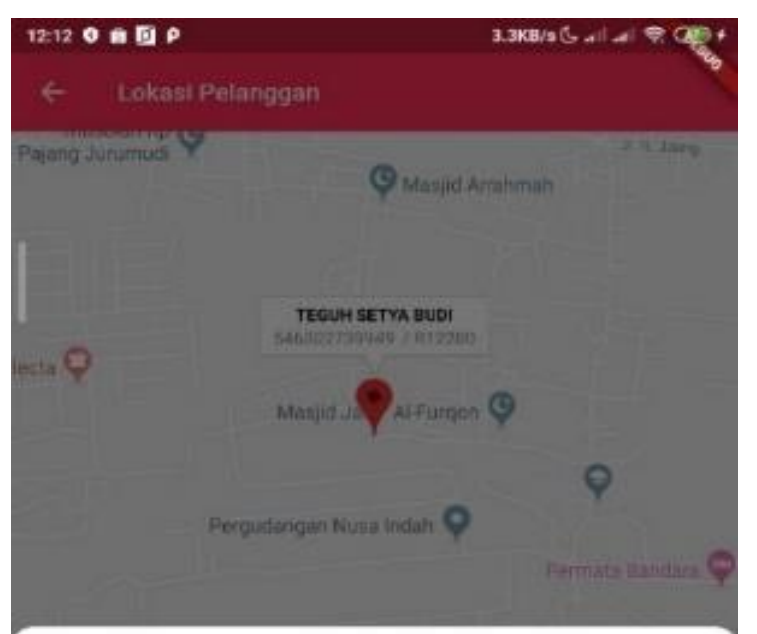

R1/2200 546302739949

Ststus pernbayaran: Menunggak

Lama menunggak 3 Bulan

Dende:

Rp. 30,000

Tindakan yang harus dilakukar: Segera lakukan: Bongkar Meter

Status tindakan

Selesal

\section{Proces inditar}

Gambar 9. Lembar Laporan 3 untuk tunggakan 3 bulan

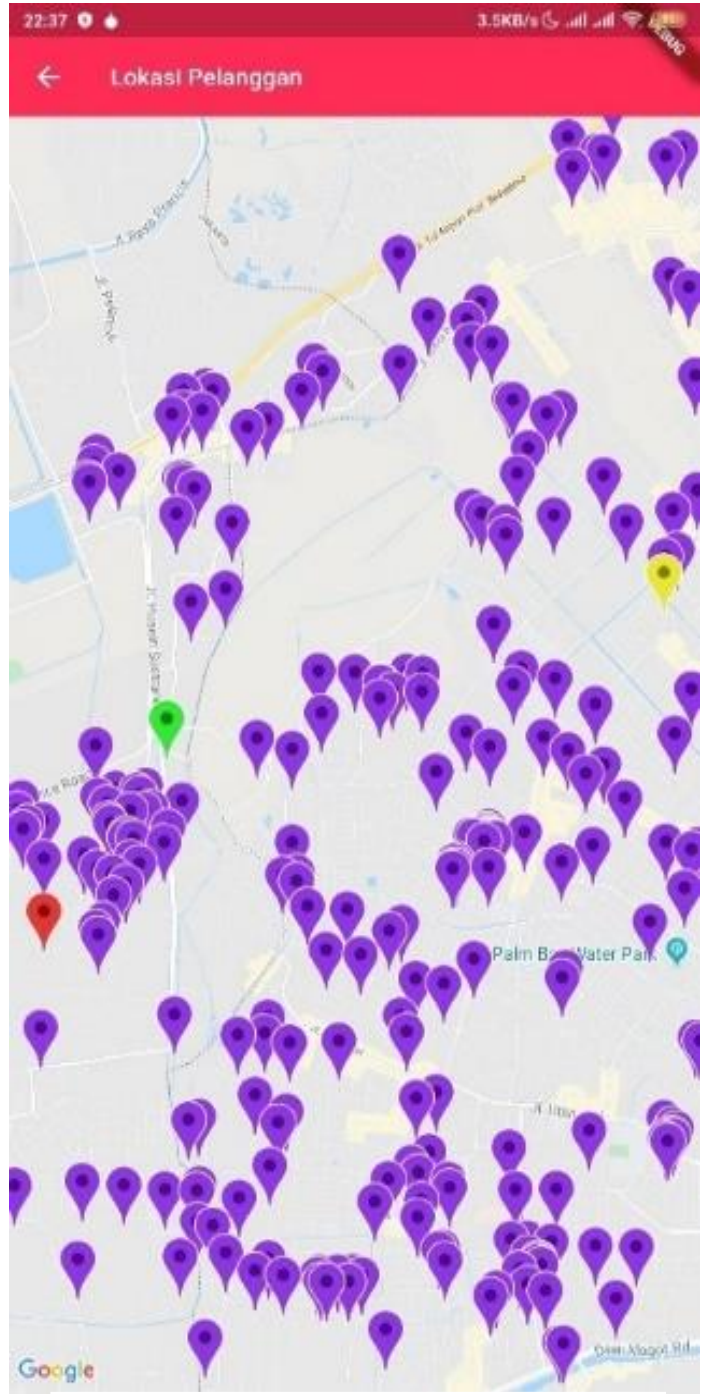

Gambar 10. Pelanggan normal atau tidak ada tunggakan

Lembar laporan seperti yang ditunjukkan pada gambar di atas memberikan informasi lebih rinci tentang status pembayaran tagihan pelanggan seperti tegangan listrik, biaya tunggakan, status pembayaran, tunggakan lama, sanksi, tindakan oleh petugas dan status tindakan. Dengan menggunakan sistem geolokasi ini, petugas mudah mengidentifikasi pelanggan mana tagihan telah dibayar atau tidak. Misalnya, gambar 7 menunjukkan tunggakan satu bulan dan lokasi pelanggan ditandai dengan titik warna hijau. Gambar 8 menunjukkan tunggakan dua bulan dan lokasi pelanggan ditandai dengan titik warna kuning. Gambar 9 menunjukkan tunggakan tiga bulan dan lokasi pelanggan ditandai dengan titik warna merah. Sanksi dan tindakan untuk setiap pelanggan juga diberi tiga warna yang dikategorikan seperti yang telah dijelaskan sebelumnya. Sedangkan warna violet seperti yang ditunjukkan pada gambar 10 menggambarkan distribusi poin pelanggan yang tagihannya telah dilunasi.

\subsection{Pemrosesan Tagging Geolokasi}

Tag geolokasi adalah konsep berbagi informasi dengan menggunakan peta secara akurat. Penandaan geografis di sini dimaksudkan untuk memberikan informasi tentang pembayaran tagihan 
pelanggan PLN. Dasar pemberian tag adalah posisi yang diambil dari Global Positiong System(GPS) termasuk sistem koordinat lintang dan bujur di semua lokasi di permukaan bumi dari 180 'di barat ke 180' di timur semua khatulistiwa dan 90 'di utara ke 90 'Di selatan semua garis meridian. Pengambilan gambar dengan penandaan geolokasi dilakukan dengan mengambil informasi dari GPS ketika gambar diambil.

Prosedur proses dokumentasi saat penandaan dapat ditampilkan sebagai berikut:

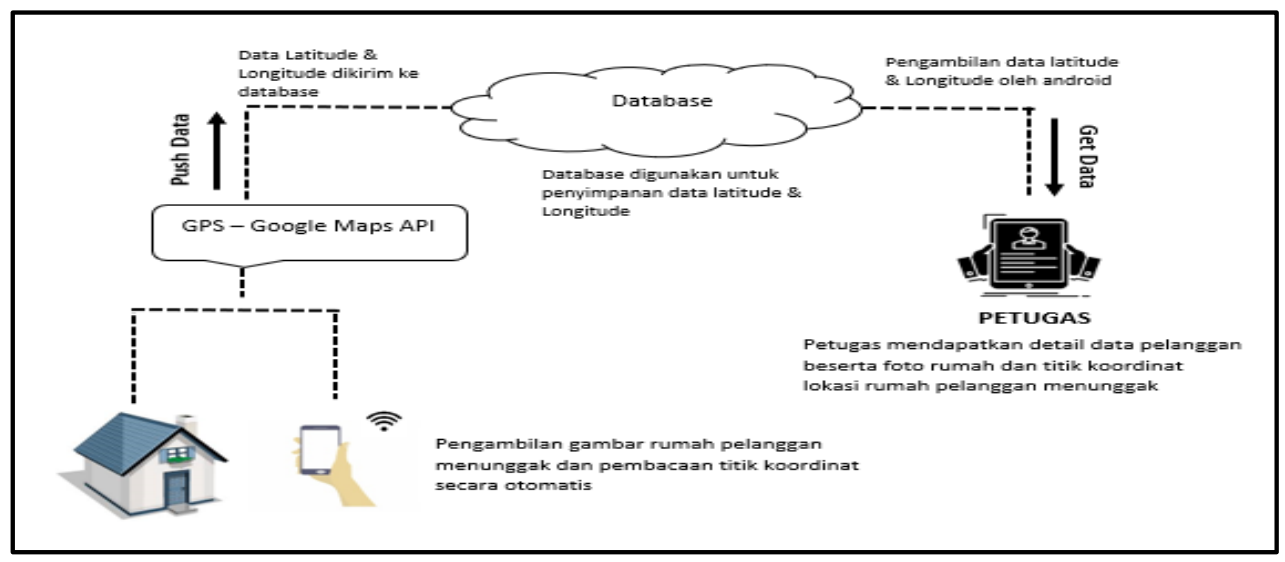

Gambar 11. Proses Tagging

Gambar 11 metode kerja deskripsi penandaan geolokasi untuk pelanggan yang belum dibayar. Ketika petugas berada di lokasi, mereka dapat melaporkan apa yang terjadi di tempat itu dengan menggunakan aplikasi penandaan untuk mengambil gambar dengan kamera. Ini adalah gambaran nyata untuk mengetahui lokasi pelanggan yang belum dibayar.

Titik koordinat lokasi akan secara otomatis diisi dengan pembacaan GPS oleh android yang terintegrasi dengan google maps API. Butuh titik koordinat saat mengambil lokasi pelanggan. Jadi, petugas tidak bingung untuk mencari lokasi dan mengoordinasikan poin. Kemudian, data pelanggan dikomplain termasuk hal penting dalam kaitannya dengan pelanggan untuk dimasukkan sebagai informasi yang lebih detail.

Gambar lokasi pelanggan termasuk titik koordinat diunggah ke dalam penandaan lokasi untuk diproses dan dicatat secara otomatis ke dalam basis data. Selanjutnya, data diproses oleh penandaan lokasi yang dimasukkan petugas ke dalamnya dan kemudian akan secara otomatis masuk ke dalam basis data. Ini diproses oleh sistem android. Konsep penerapan geotagging dalam aplikasi ini sangat efisien dan membantu petugas untuk melakukan proses penandaan lokasi pelanggan. Semua data pelanggan yang belum dibayar, seperti gambar lokasi, titik koordinat, dan informasi detail tersedia di sini. Jika dibandingkan dengan sistem penagihan konvensional sebelumnya, tentu saja sistem ini lebih baik dalam memberi dan mengetahui informasi penagihan baik dari pelanggan yang sudah membayar maupun yang belum dibayar.

\section{KESIMPULAN}

Kesimpulan dari Penelitian ini adalah sebagai berikut:

1. Implementasi Google Maps API menggunakan titik koordinat data alamat pelanggan, sehingga sistem dapat menyediakan data geospasial dari koordinat lokasi pelanggan dengan pembacaan GPS untuk mengetahui koordinat akurat dari lokasi rumah pelanggan, 
Penerapan metode Penandaan Geolokasi dapat memberikan akurasi titik lokasi pelanggan antara alamat pelanggan dari database dan Google Maps.

2. Dengan sistem ini petugas mudah memantau pelanggan PT. PLN (Persero) dalam menangani tunggakan pelanggan dan dapat mencegah pelanggan yang masih memiliki tunggakan untuk melakukan instalasi baru, membantu petugas dalam melakukan proses tindakan langsung di lokasi pelanggan sesuai dengan sanksi yang ditetapkan oleh PLN dalam hal tunggakan pelanggan.

\section{UCAPAN TERIMAKASIH}

Terimakasih yang sebesar-besarnya kami ucapkan kepada Lembaga Penelitian Pengabdian Masyarakat (LPPM) Institut Teknologi PLN yang telah membiayai Penelitian Dosen Pemula Tahun Anggaran 2019 dengan Nomor Kontrak 020/1/A01/PDP/STT-PLN/2019 Tanggal 4 Desember 2019.

\section{DAFTAR PUSTAKA}

[1] D. Hariyanto and S. A, "Faktor-Faktor Yang Mempengaruhi Pelanggan Menunggak Rekening Listrik Pada PLN Sub-Rayon Sentebang," J. Manaj. Motiv., vol. 11, no. 1, p. 585, 2016, doi: 10.29406/jmm.v11i1.62.

[2] A. Amarudin and S. Silviana, "Sistem Informasi Pemasangan Listrik Baru Berbasis Web Pada PT Chaputra Buana Madani Bandar Jaya Lampung Tengah," J. Tekno Kompak, vol. 12, no. 1, p. 10, 2018, doi: 10.33365/jtk.v12i1.65.

[3] P. Dan, "Listrik Berbasis Web," vol. 5, pp. 25-30, 2019.

[4] N. Savitri and H. Nurwasito, "Pengembangan Aplikasi Mobile untuk Pelayanan Administrasi Posyandu dengan menggunakan Google Maps Api Geolocation Tagging," J. Pengemb. Teknol. Inf. dan Ilmu Komput., vol. 2, no. No.1 Januari 2018, pp. 63-72, 2018.

[5] B. T. Wibowo and S. N. Anwar, "Rancangan Hazard Reporting System Dengan Metode Geolocation Tagging Pada Platform Android Di Pt . Angkasa Pura I ( Persero )," pp. 978-979, 2018.

[6] G. Y. SWARA and A. ZIRWAN, "Aplikasi Pencarian Barbershop Berbasis Android," J. Teknoif, vol. 6, no. 2, pp. 74-80, 2018, doi: 10.21063/jtif.2018.v6.2.74-80.

[7] W. Wijaya, H. Tolle, and A. P. Kharisma, "Rancang Bangun Aplikasi Geotagging Social Report Bencana Banjir,” J. Pengemb. Teknol. Inf. dan Ilmu Komput. Univ. Brawijaya, vol. 2, no. 7, 2018.

[8] R. K. Anas, "Aplikasi Pemantauan Lalu Lintas Yogyakarta Menggunakan Get Source Twitter Dan Google Maps Api Berbasis Web," Semnasteknomedia Online, vol. 4, no. 1, pp. 2-11, 2016.

[9] R. Herdianto, E. B. Setiawan, J. D. No, and J. Barat, "PEMBANGUNAN APLIKASI DOKUMENTASI KUNJUNGAN LAPANGAN BERBASIS MOBILE ANDROID," no. 112.

[10] P. H. Suputra, K. Yota, E. Aryanto, and N. K. Kertiasih, "Sistem Inventaris Undiksha Berbasis Mobile Dan," pp. 280-288, 2016.

[11] A. Mardani, "Sistem Informasi Geografis Pelaporan Masyarakat (SIGMA) Berbasis Foto Geotag,” J. Sist. Dan Teknol. Inf., vol. 3, no. Vol 3, No 1 (2014), 2014.

[12] Mahmoud Shaker Nasr, Ahmed Mohammed Merza, "Electrical Energy Billing System Based On Smart Meter And GSM", International Journal of Applied Engineering Research ISSN 0973-4562 Volume 10, Number 21 (2015) pp 42003-42012 
[13] Ali Nafaa Jafaar, Bashar M. Nema, "Geolocation Android Mobile Phones Using GSM/UMTS", Open Access Baghdad Science Journal Vol. 16 (1) Supplement 2019, DOI: http://dx.doi.org/10.21123/bsj.2019.16.1(Suppl.).0254

[14] M.R.M.S.B. Rathnayaka, I.D.S. Jayasinghe, EnitJayanth, S.I. Swarnajith, M.A.S.C. Manamendra, G. Wimalaratne, "Mobile Based Electricity Billing System (MoBEBIS)", International Journal of Scientific and Research Publications, Volume 3, Issue 4, April 2013 1 ISSN 2250-3153

[15] Weiwei Fu, Weiwei Fu, Dezheng Zhang, Yu Fu, Yonghong Xie, "Arrears Prediction for Electricity Customer Through Wgan-Gp”, 978-1-5090-6414-4/17/\$31.00 (02017 IEEE

[16] Zhou H, Wang Y, Wang W, et al. "Predication of Default Probability of Clients' Electricity Charges Arrears Based on Logistic Regression Model[J]". Power System Technology, 2007, 31(17):85-88. 